NBER WORKING PAPER SERIES

POLLUTION AND INTERNATIONAL TRADE IN SERVICES

Arik Levinson

Working Paper 14936

http://www.nber.org/papers/w14936

\author{
NATIONAL BUREAU OF ECONOMIC RESEARCH \\ 1050 Massachusetts Avenue \\ Cambridge, MA 02138 \\ April 2009
}

This work was done in part for the Commission for Environmental Cooperation, Fourth North American Symposium on Assessing the Environmental Effects of Trade, Phoenix, AZ, April 23, 2008. I am grateful to the National Center for Environmental Economics (NCEE) and to Resources for the Future for hosting me during parts of this research, to Mun Ho, Carl Pasurka, Jared Creason, Irene Henriques, and Chantal Line Carpentier for helpful conversations and suggestions. Roy Huntley and Rhonda Thompson at the EPA provided invaluable help interpreting the National Emissions Inventory. The views expressed herein are those of the author(s) and do not necessarily reflect the views of the National Bureau of Economic Research.

NBER working papers are circulated for discussion and comment purposes. They have not been peerreviewed or been subject to the review by the NBER Board of Directors that accompanies official NBER publications.

(C) 2009 by Arik Levinson. All rights reserved. Short sections of text, not to exceed two paragraphs, may be quoted without explicit permission provided that full credit, including $\odot$ notice, is given to the source. 
Pollution and International Trade in Services

Arik Levinson

NBER Working Paper No. 14936

April 2009

JEL No. F18,Q56

\begin{abstract}
$\underline{\text { ABSTRACT }}$
Two central topics in recent rounds of international trade negotiations have been environmental concerns, and services trade. While each is undoubtedly important, they are unrelated. In this paper I show that the services-environment link is small, for two reasons. First, services account for only a small fraction of overall pollution. For none of five major air pollutants does the service sector account for even four percent of total emissions; for three of the five services account for less than one percent. Second, those service industries that do pollute are the least likely to be traded internationally. Those services for which the U.S. collects and publishes international trade data - presumably those services that are traded internationally - are less polluting than services for which trade data do not exist presumably because the services are not traded. Even if we limit attention to the services that are traded across borders, the service industries most intensively traded are the ones that pollute the least. The bottom line is simple. International services trade bears little relation to the environment, because services in general contribute relatively little to overall pollution, and those industries that are traded internationally are among the least polluting.
\end{abstract}

\author{
Arik Levinson \\ Department of Economics ICC 571 \\ Georgetown University \\ 3700 O St., NW \\ Washington, DC 20057 \\ and NBER \\ aml6@georgetown.edu
}




\section{Pollution and International Trade in Services}

Recent rounds of international trade negotiations have increasingly addressed services, a sector that has been growing as a share of output in industrialized countries, and the negotiations have also increasingly focused on how trade affects the environment. It is natural, therefore, to link these two subjects and ask whether increased trade in services might affect the environment. In this paper I show that the services-environment link is small, for two reasons. First, services account for only a small fraction of overall pollution; and second, those service industries that do emit pollution (including through the use of intermediate inputs that themselves pollute) tend to be the ones that are least likely to be traded across international borders.

Trade in services only became a formal topic of international negotiation in 1986, with the Uruguay round of world trade talks. The Uruguay round led to the General Agreement on Trade in Services (GATS), which became law in January 1995. Meanwhile, the combined value of imports and exports of services to the U.S. grew from \$296 billion in 1987 to $\$ 1.6$ trillion in 2005 (see Table 1). Adjusted for inflation, this amounts to a 243 percent increase in international services trade. During the same period, real U.S. international goods trade grew by 153 percent. So while the service sector only makes up 38 percent of U.S. international trade, its share has been growing. It is thus easy to see why services have become increasing important to international trade negotiations.

It is also clear that the environment has become increasingly important to trade negotiations. Environmental groups have long protested trade agreements, partly out of concern that producers will relocate to countries with weak pollution regulations, 
avoiding strict regulations in developed countries and damaging the environments of developing countries. The North American Agreement on Environmental Cooperation (NAAEC) was a direct response to those concerns regarding the North American Free Trade Agreement (NAFTA). NAAEC requires participant countries enforce their own environmental regulations. The link between trade negotiations and environmental concerns was formalized in the U.S. in 1999 by Executive Order 13141, "Environmental Review of Trade Agreements." The order stipulates that "the United States will factor environmental considerations into the development of its trade negotiating objectives."

So both services and environmental concerns are attracting increasing attention during international trade negotiations. Are they linked? The evidence suggests they are not, for two reasons. Services contribute only a tiny fraction of overall pollution, even taking into account the inputs necessary to produce those services. And those services that are most heavily traded across borders are least likely to pollute. The first of these two points is simplest, so I start with that.

\section{Services account for a small fraction of pollution}

To find out how important services are to overall pollution, I examine the U.S. Environmental Protection Agency's (EPA) National Emissions Inventory (NEI). The NEI houses the EPA's repository for pollution data compiled by states and industries. It includes pollution from point, mobile, and area sources. The NEI reports emissions of common air pollutants: sulfur dioxide $\left(\mathrm{SO}_{2}\right)$, nitrogen oxides $\left(\mathrm{NO}_{\mathrm{x}}\right)$, carbon monoxide (CO), particulate matter (PM10), and volatile organic compounds (VOCs), a precursor to ozone, or "smog". I have obtained from the EPA the NEI for the year 2002, 
disaggregated by four-digit standard industrial classification (SIC) codes. ${ }^{1}$ Using those data, I separated out services from other large sources of pollution, and tabulated the data in Table 2.

Table 2 reports the share of overall pollution emitted by each sector. For none of the five air pollutants does the service sector account for even five percent of the total. For the largest, VOCs, the service sector accounts for only 3.7 percent of total emissions. In fact, the top row of Table 2 probably exaggerates the pollution from services that could potentially be traded internationally. One particularly large polluting service, transportation, does not necessarily belong. While transportation services are traded internationally, that trade does not alter the location of the activity, or of the pollution generated. An American can purchase airline travel from Montreal to Washington D.C. from either a Canadian or an American carrier. Goods can be shipped across the United States by American trucking companies or, under the NAFTA rules, Mexican or Canadian companies. In no case, however, does the international trade change the location of the economic activity. Importing the transportation does not change the route the plane or truck travels, only who gets paid. In cases such as transportation, where international trade merely involves a flow of payments, and does not affect the location of the polluting activity, no trade-environment link exists.

There are, however, several counter-arguments to eliminating transport from the analysis - and even some reasons why the transport component may be understated. If increased international trade lowers the cost of transportation services, through economies of scale, there may be even more transport as a consequence, and hence more

\footnotetext{
${ }^{1}$ Correspondence with Roy Huntley, U.S. EPA.
} 
pollution from transportation. More importantly, transport is an input into many goods and services. In the analyses that follow, I take into account the pollution caused by intermediate imports, including transport, to the extent those inputs are used in current production methods. If international trade increases, transport will increase as a fraction of all goods and services, increasing their emissions total per dollar of output. Accounting for these second-order effects is beyond the scope of this discussion, which simply notes that services do not contribute much to overall pollution, and traded services contribute even less.

If we do eliminate transportation from the list of services, the pollution from the remainder of the service sector accounts for less than one percent of total pollution in the U.S. (See the second row of Table 2.) For the largest, still VOCs, services now account for only 0.7 percent of total U.S. emissions.

There is, however, one caveat to the calculations in Table 2. Some service industries may not pollute very much directly, but may use inputs whose production generates pollution. Or, they may use inputs whose production uses other inputs that pollute, and so on. Some of the manufactured goods that emit 70 percent of the $\mathrm{CO}$ in the United States may be used as inputs to service industries. If we import those services, the location of that manufacturing activity may change as well, which means the environmental consequences of services trade may be larger than suggested by Table 2 .

To account fully for the complications arising from intermediate inputs, I use an industry-by-industry accounting for pollution emitted in the U.S., developed by the EPA, that includes both direct pollution and pollution generated indirectly by inputs. With those data I can both account for the concern about intermediate inputs, and demonstrate 
that the services share of total pollution is still small, and that those industries that pollute are the least likely to be traded.

\section{Polluting services are less traded internationally}

To demonstrate a link between pollution intensity and trade intensity, we first need definitions and data for both concepts.

\section{Calculating trade intensity}

The U.S. Bureau of Economic Analysis (BEA) publishes annual statistics about international trade in services (Koncz and Flatness, 2007). The BEA documents two types of international services transactions, sales through foreign affiliates and crossborder trade. The first, sales through foreign affiliates, does not involve changing the location of the service activities. U.S. imports of services via foreign affiliates occur whenever a U.S. resident purchases a service in the U.S. from a company that is majorityowned by a foreign country. U.S. exports of services via foreign affiliates occur whenever a resident of a foreign country purchases a service from a company that is majority owned by the U.S. In neither case is the location of the service, or the pollution generated by the service, shifted as a result of trade. All that changes is the ownership of the company providing the service. According to the BEA, sales through affiliates

"are not considered U.S. international transactions, because under the residency principle of balance-of-payments accounting, affiliates of multinational companies are regarded as residents of the countries where they are located rather than of the countries of their owners." 
Accordingly, and because sales through affiliates do not change the location of pollution, I ignore this first type of international services trade in the rest of this analysis. ${ }^{2}$

The second channel of international services trade, cross-border trade, will be the focus here. This includes trades between unrelated parties and intra-firm exchanges within multinational companies. These are recorded as exports and imports in the seller and buyer countries' international accounts. To calculate the trade intensity of these types of services, I add the values of exports and imports, and divide by total output.

Turning again to Table 1, we can see that much of the growth in services has come from these majority-owned foreign affiliates. In fact, if we limit the analysis to cross-border trade, total services trade in the U.S. has grown more at about the same pace as total goods trade -- 162 percent compared with 153 percent in real terms. Or, put differently, the ratio of cross-border trade to total goods trade was 0.24 in 1987 and 0.25 in 2005 -- essentially flat. Meanwhile the ratio of sales through affiliates trade to total goods trade grew from 0.2 in 1987 to 0.36 in 2005 (see columns 4 and 8). So the growth of services trade has come mostly via channels that do not relocate pollution, and for which there is therefore no direct trade-environment link.

\section{Calculating pollution intensity}

To calculate the pollution intensity of service industries, I rely on the U.S. EPA's Trade and Environmental Assessment Model (TEAM), which reports a list of emissions intensities for each six-digit North American Industry Classification System (NAICS)

\footnotetext{
${ }^{2}$ One could argue that opportunities for sales through affiliates, via foreign direct investment, increase economic activity and therefore pollution. That is a secondary scale effect that I ignore by necessity for sales through affiliates as well as for cross-border trade.
} 
code. These industry-by-industry emissions intensities were calculated by the U.S. EPA and Abt Associates (2004) specifically to assess the environmental effects that might arise from international trade agreements. TEAM is based on the $1997 \mathrm{NEI}$ and can be used to generate emissions factors (environmental consequences per dollar of output) for 1,099 six-digit NAICS industry codes, and for more than 1,000 different environmental outcomes, including air pollutants, individual toxic chemicals, hazardous waste, and land use. Here I focus on the NAICS codes that comprise the services sector, and common air pollutants for which there are sufficient data on emissions by traded service industries.

Note that by construction these TEAM emissions coefficients only contain information about pollution in the U.S. We cannot use the coefficients to say anything about pollution changes overseas that result from changing imports or exports to the U.S. If we see increased U.S. exports of a service, we can use the coefficients to tell us how much pollution those exports are causing where they are produced, in the U.S. If we see increased U.S. imports of a service, we can use the coefficients to estimate how much pollution would have been emitted in the U.S. had those imports instead been produced domestically. In general, I think of this concept as the U.S. pollution "displaced" by trade. We can use the TEAM coefficients to estimate the amount of pollution that would have been caused in the U.S. had imports been produced locally, or the amount of pollution emitted in the U.S. as a consequence of producing goods for export.

Table 3a displays these direct TEAM emissions coefficients for each broad category of services, as defined by the U.S. Census Bureau. They are calculated by taking a weighted average of the emissions coefficients for each 6-digit NAICS code, 
where the weights are industry's sales in 1997. Not surprisingly, transportation and waste remediation are the two most polluting services.

There is, however, one complication mentioned above - the role of pollution generated by intermediate inputs. If we simply rely on direct TEAM emissions factors, we only measure the pollution emitted by each industry in production of its final output. This would understate the pollution associated with a given change in services trade, because pollution from intermediate inputs would be ignored.

A simple example may help to explain the problem. One internationally traded service is industrial machinery repair and maintenance (NAICS code 8113). U.S. airlines, for example, increasingly outsource their maintenance to other countries, including Mexico, China, and the Philippines. ${ }^{3}$ The process of repairing an airplane does emit pollution, including volatile organic compounds used in solvents. But the manufacture of those solvents also involves pollution. Suppose that initially airplanes are maintained in the United States, that maintaining planes requires solvent as an input, and that solvent is entirely produced domestically. If the U.S. decides to outsource airplane maintenance, pollution will decline in the U.S. for two reasons: a reduction in airplane maintenance, and a reduction in solvent production.

How much of the decline in U.S. pollution can be attributed to the increase in imported maintenance services? In this example, we can account for 100 percent, by construction. The reduction in airplane maintenance will be reflected in the increased imports of maintenance services. But the reduction in solvent production will not, because there are no solvent imports. If we simply multiply the change in imported

\footnotetext{
3 Reuters. February 11, 2008. "Airline Outsourcing Endangering Passengers, National Security, Say Aviation Mechanics."
} 
maintenance services by the respective direct emissions coefficient for maintenance services, from TEAM, we will understate the pollution displaced by imports. The change in solvent production occurs abroad and is embodied in the airplane maintenance. The direct emissions coefficients understate the amount of U.S. pollution reduction that would be the consequence of increased service imports.

To account for intermediate inputs properly, we need to account for not only the pollution embodied in the intermediate inputs to imported services, but also the pollution embodied in the intermediate inputs to those intermediate inputs, and so on ad infinitum. (The solvent used in maintaining the plane itself requires chemical inputs that may produce pollution, and so on.) For this calculation, the EPA and Abt used a basic Leontief input-output framework to estimate the pollution caused by production of final output, including intermediate inputs. ${ }^{4}$

Suppose that an $n \times n$ matrix $\mathbf{C}$ has elements $c_{i j}$ representing the dollar value of input industry $i$ needed to produce one dollar's worth of output industry $j$. Then we can write the total output, $\mathbf{x}$, a vector of $n$ outputs - one from each industry - as the sum of output used as intermediate goods and final output, $\mathbf{y}$.

$$
\left[\begin{array}{c}
x_{1} \\
\vdots \\
x_{n}
\end{array}\right]=\left[\begin{array}{ccc}
c_{11} & \cdots & c_{1 n} \\
\vdots & \ddots & \vdots \\
c_{n 1} & \cdots & c_{n n}
\end{array}\right]\left[\begin{array}{c}
x_{1} \\
\vdots \\
x_{n}
\end{array}\right]+\left[\begin{array}{c}
y_{1} \\
\vdots \\
y_{n}
\end{array}\right]
$$

Or, in vector notation:

$$
\mathbf{x}=\mathbf{C x}+\mathbf{y}
$$

\footnotetext{
${ }^{4}$ See, for example, Miller and Blair (1985).
} 
If we were examining changes in U.S. production, we would observe $\mathbf{x}$, the value of all output, including both intermediate inputs and final products. Pollution could be approximated by multiplying $\mathbf{x}$ by a vector of direct emissions coefficients, $\mathbf{z}$, such as those from TEAM. But when we examine trade flows, we see only the final product $\mathbf{y}$, without the production of intermediate inputs. In this case, we need a set of total pollution coefficients. These coefficients must embody all the pollution generated by all of the inputs to $\mathbf{y}$, all the inputs to those inputs, and so on. To calculate this, solve equation (2) for $\mathbf{x}$ to get

$$
x=[I-C]^{-1} y=T y
$$

where $\mathbf{I}$ is the identity matrix.

The matrix $\mathbf{T}=[\mathbf{I}-\mathbf{C}]^{-\mathbf{1}}$ is a standard Leontief total requirements matrix. Each element $t_{i j}$ contains the dollar amount of industry $i$ necessary to produce one dollar of output industry $j$, including the amount of $i$ used in all other industries that are used in $j$, as well as the amount of $i$ used in the inputs to those industries, and so forth. The vector $\mathbf{x}$ represents the total amount of manufactured goods necessary to produce output $\mathbf{y}$. To generate the total pollution coefficients, premultiply the Leontief total requirements matrix by the $\mathbf{z}$ vector from TEAM as follows:

$$
\tilde{\mathbf{z}}=\mathbf{z}^{\prime} \mathbf{T}=\mathbf{z}^{\prime}[\mathbf{I}-\mathbf{C}]^{-1}
$$

The only new information needed to construct $\tilde{\mathbf{z}}$ is $\mathbf{C}$. That information can be found in the input-output tables for the United States published periodically by the BEA. The EPA used the 1997 input-output tables to create an estimate of $\mathbf{C}$ and to translate direct emissions coefficients, $\mathbf{z}$, into total emissions coefficients, $\tilde{\mathbf{z}}$, using equation (4). 
Using the total emissions coefficients, $\tilde{\mathbf{z}}$, in place of the direct emissions coefficients, $\mathbf{z}$, captures all of the pollution generated by intermediate goods, and does not understate pollution displaced by traded services. Unfortunately $\tilde{\mathbf{z}}$ instead overstates pollution displaced by traded services. If the solvents used to maintain airplanes in the United States are entirely imported, importing maintenance from abroad displaces no U.S. solvent production, and the appropriate emissions coefficient is the direct one (z).

The two emissions coefficients, direct (z) and total ( $\tilde{\mathbf{z}})$, thus constitute lower and upper bounds on the amount of U.S. pollution displaced whenever a service is imported. The direct coefficient assumes there are no polluting intermediate goods, or that all polluting intermediates were themselves imported. The total coefficient assumes all intermediate inputs, as well as the inputs to those inputs, were entirely produced within the U.S. In the analyses below I will present both calculations, but then use the total coefficient, which overstates pollution from services, in order to be conservative in my argument that internationally traded services account for little pollution.

Table $3 \mathrm{~b}$ displays the total emissions coefficients $\left(\tilde{z}_{i}\right)$, including pollution generated by intermediate inputs. These are typically three times as large as the direct coefficients in Table 3a.

\section{Only some services have data on cross-border trade}

The U.S. BEA collects data on international services trade for only a few industries (Koncz \& Flatness, 2007; Wichard and Borga, 2002). One natural presumption is that there simply is no international trade in the other service industries. The dollar values of international trade in haircuts, taxi rides, window-washing, etc. are 
so small as to be not worth tracking or reporting. If this is true, then the main point of this paper can be made quite simply. Those services that are traded internationally, and for which the BEA reports trade data, are the least polluting service sectors of the economy.

Table 4 makes this point. The top row reports the average pollution (per \$million of output) for the entire service sector. This is the same as the bottom row of Table 3a. The second row of Table 4 reports that same weighted average for the industries for which BEA publishes cross-border trade data. The average pollution emitted by these traded industries is much smaller. The top panel uses the TEAM pollution coefficients that understate total pollution because they only count the pollution emitted directly from producing final output. These coefficients understate the pollution from both the "all services" and "cross-border trade" categories, and including pollution from intermediate inputs is unlikely to change the result that traded services are the least polluting.

To check this, in the bottom panel of Table 4 I report the same calculation using the total emissions coefficients ( $\tilde{\mathbf{z}}$ ), including pollution from intermediate goods. This overstates pollution from the services sector (line (3)) because it double-counts services used as inputs to other services, and it overstates pollution relocated by trade because traded final product need not change the production location of intermediate inputs. The basic point remains. Those services for which the U.S. BEA collects international trade data - presumably those services that are traded internationally - are the least polluting. This is clear whether we use the direct emissions coefficients for final product only, or the total emissions coefficients counting intermediate inputs. 
Among traded services, those traded more pollute less

Finally, among those services for which the U.S. BEA collects international trade data, the industries most intensively traded are the ones that pollute the least. Table 5 supports this claim. It presents data for each of the 11 industries where the BEA collects international trade information, and where the BEA category corresponds closely to the NAICS classifications.

Column (1) of Table 5 reports the trade intensity for each of the industries. This is simply total imports plus exports over domestic production. The two services with the most international trade are reinsurance (NAICS 52413), driven by $\$ 12$ billion worth of imports in 2002, and education (NAICS 611), driven by $\$ 13$ billion worth of exports. Given the nature of these two industries, it is immediately obvious that more heavily traded industries pollute less.

Columns (2) through (7) report the pollution intensities, including intermediate inputs, for each of the industries and for each of the six pollutants. Below the industryspecific data, I report the raw correlations between trade intensity (column (1)), and the relevant pollution intensities. All of the correlations are negative except for VOCs. The positive VOC correlation is driven by the last industry, commercial and industrial machinery repair and maintenance (NAIC 8113), which has both high pollution and high international trade. If I drop industry 8113 from the correlation, they all become even more negative, including the VOC correlation.

The negative relationship between trade intensity and pollution intensity is not driven by the two outliers, education and reinsurance. At the bottom of Table 5, I report 
the correlations excluding those two industries. Again, all of the correlations, except for VOCs, are negative, even omitting those two heavily traded, non-polluting industries.

Are these results different for trade within NAFTA?

A final concern one might have involves the degree to which trade agreements or geographic proximity affect the conclusion that traded services do not pollute. Services trade with neighboring countries might be different than services trade with far distant countries. Or, trade agreements such as the NAFTA may alter the pollution-intensity of services trade.

At the very bottom of Table 5, I report the correlations between the pollution intensity and the trade intensity of each industry with Canada and Mexico, respectively. If anything, this makes the case stronger. The correlations between pollution intensity and services trade with Canada is, for every pollutant, more negative that for trade with all countries. The correlations for trade with Mexico are more negative for four of the six pollutants. Limiting the analysis to the NAFTA countries does not alter the conclusion that traded services are the least polluting.

An aside: Tourism

Several readers of early drafts expressed concern that the analysis omits tourism, an increasingly important international service transaction with potential environmental consequences. The concern is half correct. In the first part of this analysis, where I show that services account for only a small fraction of overall pollution, tourism is included in the analysis. Tourists make use of many different service industries, mostly drawn from 
NAICS codes 71 (Arts, entertainment, and recreation) and 72 (Accommodation and food services). These industries are included in the calculation in Table 2 where I show that services as a whole account for only 2.3 percent of carbon monoxide emissions, 0.93 percent of nitrogen oxide emissions, etc. And tourism is included in Table 3 where I document the pollution intensity of various service industries. Though the table cannot separate which hotel rooms and Broadway shows are purchased by tourists and which by natives, that distinction is unimportant to make the point that services as a whole, including tourism, contribute relatively little to overall pollution. So for this first part of the analysis, the concern about tourism being omitted is misplaced.

Where the concern about omitted tourism rings true involves the second part of the analysis, where I show that polluting services are less traded internationally. Tourism is traded internationally, but the BEA data do not include most of those activities. ${ }^{5}$ So in Table 4, tourism is not included in rows (2) and (4), listing the pollution intensity of service industries for which the BEA published cross-border trade data. And in Table 5, tourism is mostly omitted from the list of industries, and from the trade intensities in column (1).

Does this omission weaken the claim that internationally traded services are less polluting? No. Look at Table 3b, and assume that NAICS codes 71 and 72 are entirely tourism and entirely traded internationally. Those two service industries are among the least pollution intensive. Only information, education and health care are consistently less pollution intensive. If I could somehow include tourism separately in Tables 4 and 5, that would be one more highly traded relative clean industry, making the correlation

\footnotetext{
${ }^{5}$ The BEA data includes cross-border expenditures on tour agencies and reservations, but not the direct expenditures by foreign tourists on U.S. services, or services purchased by U.S. tourists abroad.
} 
between trade intensity and pollution intensity even more negative. The concern about tourism's omission therefore has no effect on the first conclusion, that services contribute little to pollution, and makes the second conclusion even stronger, that traded services pollute relatively less.

\section{Conclusions}

The analysis abstracts from several complications. Increased international trade may increase the amount of transportation used as an input to many goods and services, increasing their emissions. Some of the traded services may be aimed directly at reducing pollution - environmental consulting, technology transfer, etc. And international trade and investment may increase the scale of economic activity - for both services and goods - and increase pollution accordingly. But these concerns depart from the focus of this paper, which asks whether trade in services affects environmental quality by changing the composition of industries in the exporting or importing countries.

Also, the focus here has been on conventional air pollutants. I cannot rule out the possibility that had I focused instead on toxic air pollution, water pollution, or hazardous waste, the conclusions might have been different.

The point here is simple. International trade has important links to the environment, and service industries are important to international trade, but international trade in services bear little relation to the environment. Why? Services contribute relatively little to overall pollution, and those industries that are traded internationally are among the least polluting. 


\section{References}

Cole, Matthew A. 2004. "U.S. environmental load displacement: examining consumption, regulations and the role of NAFTA" Ecological Economics 48(4): 439-450.

Ederington, Josh, Arik Levinson, and Jenny Minier. 2004. "Trade Liberalization and Pollution Havens." Advances in Economic Policy and Analysis 4(2). Berkeley Electronic Press.

Gamper-Rabindran, Shanti. 2006. "NAFTA and the Environment: What Can the Data Tell Us?" Economic Development and Cultural Change 605-633.

Hettige, Hemamala, Paul Martin, Manjula Singh, and David Wheeler. 1995. "The Industrial Pollution Projection System." World Bank Policy Research Working Paper \#1421. Washington, DC, March 1995.

Kahn, Matthew E. 2003. "The Geography of U.S. Pollution Intensive Trade: Evidence from 1959 to 1994." Regional Science and Urban Economics 33(4): 383-400.

Koncz, Jennifer, and Anne Flatness. 2007. "U.S. International Services: Cross-Border Trade in 2006 and Sales Through Affiliates in 2005." Survey of Current Business. October.

Levinson, Arik. 2007. "Technology, International Trade, and Pollution from U.S. Manufacturing" NBER working paper no w13616.

Miller, R.E., and P.D. Blair. 1985. Input-Output Analysis: Foundations and Extensions. Englewood Cliffs, NJ: Prentice-Hall.

Runge, C. Ford. 1995. "Trade, Pollution, and Environmental Protection" in Handbook of Environmental Economics, Daniel W. Bromley, ed. Wiley, New York, NY.

Schatan, Claudia. 2003. "The Environmental Impact of Mexican Manufacturing Exports under NAFTA" in Greening NAFTA, Markell, David and John Knox, eds. Stanford University Press, Stanford CA.

U.S. Environmental Protection Agency. 2000. "National Air Pollutant Emission Trends, 1900-1988," EPA-454/R-00-002. Office of Air Quality Planning and Standards, U.S. Environmental Protection Agency, Research Triangle Park, NC. March 2000.

U.S. Environmental Protection Agency. 2004. "Trade and Environmental Assessment Model: Model Description." Prepared for U.S. EPA, National Center for Environmental Economics, by Abt Associates, Inc.. Cambridge, MA. 
Whichard, Obie G. and Maria Borga. 2002. "Selected Issues in the Measurement of U.S. International Services" Survey of Current Business June 2002.

World Trade Organization (WTO). 2006. "The General Agreement on Trade in Services: An Introduction" mimeo. March 292006. 
Table 1. Services trade is growing faster than goods trade, due to sales through affiliates.

\begin{tabular}{|c|c|c|c|c|c|c|c|c|c|c|c|c|}
\hline \multirow[b]{3}{*}{ Year } & \multicolumn{9}{|c|}{$\begin{array}{l}\text { U.S. Services Trade } \\
\text { (\$billions) }\end{array}$} & \multicolumn{3}{|c|}{$\begin{array}{l}\text { U.S. Goods Trade } \\
\text { (\$billions) }\end{array}$} \\
\hline & \multicolumn{3}{|c|}{$\underline{\text { X-border }}$} & \multicolumn{6}{|c|}{ Sales through affiliates } & & & \\
\hline & $\begin{array}{c}\text { Exports } \\
(1)\end{array}$ & $\begin{array}{l}\text { Imports } \\
(2)\end{array}$ & $\begin{array}{c}\text { Total } \\
(3)\end{array}$ & $\begin{array}{c}\text { Ratio to } \\
\text { Total } \\
\text { Goods } \\
\text { [(3)/(12)] } \\
(4)\end{array}$ & $\begin{array}{c}\text { Exports } \\
(5)\end{array}$ & $\begin{array}{c}\text { Imports } \\
(6)\end{array}$ & $\begin{array}{l}\text { Total } \\
(7)\end{array}$ & $\begin{array}{l}\text { Ratio to } \\
\text { Total } \\
\text { Goods } \\
{[(7) /(12)]} \\
(8)\end{array}$ & $\begin{array}{c}\text { Total } \\
\text { Services } \\
(9) \\
\end{array}$ & $\begin{array}{l}\text { Exports } \\
(10\end{array}$ & $\begin{array}{l}\text { Imports } \\
(11)\end{array}$ & $\begin{array}{c}\text { Total } \\
\text { Goods } \\
(12) \\
\end{array}$ \\
\hline 1987 & 87.0 & 73.9 & 160.9 & 0.24 & 72.3 & 62.6 & 134.9 & 0.20 & 295.8 & 250.2 & 409.8 & 660.0 \\
\hline 2005 & 367.8 & 281.6 & 649.4 & 0.25 & 528.5 & 389.0 & 917.5 & 0.36 & 1566.9 & 894.6 & 1681.7 & 2576.4 \\
\hline$\%$ change (nominal) & 323 & 281 & 304 & & 631 & 521 & 580 & & 430 & 258 & 310 & 290 \\
\hline$\%$ change (real) & 173 & 147 & 162 & & 374 & 303 & 341 & & 243 & 132 & 166 & 153 \\
\hline
\end{tabular}

Source: Koncz and Flatness (2007).

Note: real values calculated using GDP price deflator between 1987 and 2005 (1.54). 
Table 2. Services percent of total pollution is small.

\begin{tabular}{|c|c|c|c|c|c|}
\hline \multirow[b]{2}{*}{ Sector } & \multicolumn{5}{|c|}{$\begin{array}{l}\text { Share of total emissions: } 2002 \\
\text { (percent) }\end{array}$} \\
\hline & $\begin{array}{l}\mathrm{CO} \\
(1)\end{array}$ & $\begin{array}{l}\text { NOx } \\
(2)\end{array}$ & $\begin{array}{l}\text { PM10-FIL } \\
\text { (3) }\end{array}$ & $\begin{array}{l}\mathrm{SO} 2 \\
(4)\end{array}$ & $\begin{array}{l}\text { VOC } \\
(5)\end{array}$ \\
\hline Services & 2.30 & 0.93 & 0.77 & 0.46 & 3.69 \\
\hline - without transport & 0.65 & 0.56 & 0.47 & 0.44 & 0.72 \\
\hline Manufacturing & 69.60 & 19.98 & 51.56 & 15.75 & 74.42 \\
\hline Utilities & 21.37 & 74.06 & 36.04 & 82.69 & 6.86 \\
\hline Extractive industries & 4.89 & 4.73 & 8.42 & 1.01 & 10.59 \\
\hline $\begin{array}{l}\text { Source: US EPA Nation } \\
\text { Pollutants: } \\
\text { - CO: carbon monoxid } \\
\text { - NOx: nitrogen dioxid } \\
\text { - PM10-FIL particulate } \\
\text { - SO2: sulfur dioxide. } \\
\text { - VOC: volatile organic }\end{array}$ & naller th & $\begin{array}{l}\text { ry } 2002 . \\
10 \text { micro }\end{array}$ & filterable. & & \\
\hline
\end{tabular}


Table 3a. Pollution directly from each service sector, 2002.

\begin{tabular}{|c|c|c|c|c|c|c|c|c|}
\hline \multirow[b]{2}{*}{ NAICS } & \multirow[b]{2}{*}{ Description } & \multirow{2}{*}{$\begin{array}{c}\text { Sales } \\
\text { (\$millions) } \\
(1)\end{array}$} & \multicolumn{6}{|c|}{ Pounds per \$million } \\
\hline & & & $\begin{array}{l}\mathrm{CO} \\
(2)\end{array}$ & $\begin{array}{l}\mathrm{SO} 2 \\
(3)\end{array}$ & $\begin{array}{l}\mathrm{NO} 2 \\
(4)\end{array}$ & $\begin{array}{l}\text { VOC } \\
(5)\end{array}$ & $\begin{array}{l}\text { PM10 } \\
(6)\end{array}$ & $\begin{array}{l}\text { Air toxics } \\
(7)\end{array}$ \\
\hline $48-49$ & Transportation \& warehousing & 382,152 & 25,689 & 2,310 & 24,517 & 3,362 & 1,147 & 383 \\
\hline 51 & Information & 891,846 & 705 & 16 & 116 & 72 & 7 & 29 \\
\hline 52 & Finance \& insurance & $2,803,855$ & 772 & 71 & 72 & 96 & 25 & 124 \\
\hline 53 & Real estate \& rental \& leasing & 335,588 & 8,339 & 490 & 4,739 & 917 & 268 & 212 \\
\hline 54 & $\begin{array}{l}\text { Professional, scientific, \& technical } \\
\text { services }\end{array}$ & 886,801 & 1,235 & 67 & 207 & 139 & 782 & 86 \\
\hline 55 & $\begin{array}{l}\text { Management of companies \& } \\
\text { enterprises }\end{array}$ & 107,064 & 477 & 49 & 42 & 56 & 12 & 97 \\
\hline 56 & $\begin{array}{l}\text { Administrative \& support \& waste } \\
\text { management \& remediation service }\end{array}$ & 432,578 & 56,165 & 248 & 2,314 & 5,801 & 688 & 403 \\
\hline 61 & Educational services & 30,691 & 651 & 57 & 54 & 52 & 9 & 87 \\
\hline 62 & Health care \& social assistance & $1,207,300$ & 1,171 & 43 & 184 & 166 & 16 & 90 \\
\hline 71 & Arts, entertainment, \& recreation & 141,904 & 1,206 & 619 & 2,145 & 256 & 171 & 138 \\
\hline 72 & Accommodation \& food services & 449,499 & 1,226 & 72 & 204 & 140 & 32 & 176 \\
\hline 81 & $\begin{array}{l}\text { Other services (except public } \\
\text { administration) }\end{array}$ & 307,049 & 1,684 & 539 & 973 & 5,301 & 81 & 964 \\
\hline TOTAL & & $7,976,326$ & 6,258 & 265 & 2,117 & 864 & 243 & 178 \\
\hline
\end{tabular}

Source: calculations from TEAM. This understates total pollution because it ignores pollution from intermediate goods. 
Table 3b. Pollution from each service sector, including indirectly from intermediate inputs, 2002.

\begin{tabular}{|c|c|c|c|c|c|c|c|}
\hline \multirow{2}{*}{\multicolumn{2}{|c|}{ NAICS Description }} & \multicolumn{6}{|c|}{ Pounds per \$million } \\
\hline & & \multirow{2}{*}{$\begin{array}{l}\mathrm{CO} \\
(2) \\
76,661\end{array}$} & \multirow{2}{*}{$\begin{array}{l}\begin{array}{l}\mathrm{SO} 2 \\
(3)\end{array} \\
6,892\end{array}$} & \multirow{2}{*}{$\begin{array}{l}\text { NO2 } \\
(4) \\
73,154\end{array}$} & \multirow{2}{*}{$\begin{array}{l}\begin{array}{l}\text { VOC } \\
(5)\end{array} \\
10,029\end{array}$} & \multirow{2}{*}{$\begin{array}{l}\text { PM10 } \\
(6) \\
3,425\end{array}$} & \multirow{2}{*}{$\begin{array}{l}\text { Air toxics } \\
(7) \\
1,144\end{array}$} \\
\hline $48-49$ & Transportation \& warehousing & & & & & & \\
\hline 51 & Information & 2,383 & 54 & 392 & 242 & 23 & 97 \\
\hline 52 & Finance \& insurance & 2,746 & 251 & 256 & 341 & 88 & 442 \\
\hline 53 & Real estate \& rental \& leasing & 30,691 & 1,805 & 17,419 & 3,378 & 989 & 781 \\
\hline 54 & Professional, scientific, \& technical services & 4,550 & 246 & 763 & 511 & 2,865 & 317 \\
\hline 55 & Management of companies \& enterprises & 8,983 & 921 & 786 & 1,048 & 225 & 1,831 \\
\hline 56 & $\begin{array}{l}\text { Administrative \& support \& waste } \\
\text { management \& remediation service }\end{array}$ & 146,048 & 646 & 6,007 & 15,097 & 1,791 & 1,049 \\
\hline 61 & Educational services & 668 & 59 & 55 & 53 & 9 & 89 \\
\hline 62 & Health care \& social assistance & 1,230 & 45 & 193 & 175 & 17 & 95 \\
\hline 71 & Arts, entertainment, \& recreation & 1,549 & 797 & 2,746 & 329 & 220 & 178 \\
\hline 72 & Accommodation \& food services & 3,525 & 207 & 587 & 404 & 92 & 505 \\
\hline 81 & Other services (except public administration) & 3,192 & 1,022 & 1,845 & 10,047 & 154 & 1,828 \\
\hline \multicolumn{2}{|c|}{ TOTAL } & 19,263 & 816 & 6,517 & 2,661 & 748 & 547 \\
\hline
\end{tabular}

Source: calculations from TEAM. This overstates total pollution because it double-counts pollution from intermediate goods. 
Table 4. Services traded internationally are the least polluting.

\begin{tabular}{ccccccc} 
& \multicolumn{7}{c}{ Air Pollutants (Pounds/\$million) } \\
\cline { 2 - 6 } & CO & SO2 & NO2 & VOC & PM10 & Toxics to air \\
$(1)$ & $(2)$ & $(3)$ & $(4)$ & $(5)$ & (6) \\
\hline
\end{tabular}

Direct pollution, ignoring intermediates

\begin{tabular}{llcccccc} 
(1) $\quad$ All service industries & 6,258 & 265 & 2,117 & 864 & 243 & 178 \\
$\begin{array}{l}\text { Service industries for } \\
\text { which BEA publishes } \\
\text { x-border trade data }\end{array}$ & 1,262 & 80 & 115 & 107 & 15 & 148 \\
\hline
\end{tabular}

$\underline{\text { Total pollution, including via intermediate inputs }}$

$\begin{array}{llcccccc}\text { (3) } \quad \text { All Service Industries } & 19,263 & 816 & 6,517 & 2,661 & 748 & 547 \\ \begin{array}{l}\text { Service industries for } \\ \text { (4) } \begin{array}{l}\text { which BEA publishes } \\ \text { x-border trade data }\end{array}\end{array} & 3,965 & 221 & 530 & 420 & 72 & 291 \\ \end{array}$


Table 5. Among traded services, those traded more pollute less - Indirect pollution including intermediate inputs.

\begin{tabular}{|c|c|c|c|c|c|c|c|c|}
\hline NAICS & Description & $\begin{array}{c}\text { Imp. + exp. as a } \\
\text { percent of } \\
\text { domestic sales } \\
(1)\end{array}$ & $\begin{array}{l}\text { CO } \\
(2)\end{array}$ & $\begin{array}{c}\text { SO2 } \\
(3)\end{array}$ & $\begin{array}{c}\mathrm{NO2} \\
(4)\end{array}$ & $\begin{array}{c}\text { VOC } \\
(5)\end{array}$ & $\begin{array}{l}\text { PM10 } \\
(6)\end{array}$ & $\begin{array}{l}\text { Air } \\
\text { toxics } \\
(7)\end{array}$ \\
\hline 5133 & Telecommunications & 2.02 & 5,018 & 39 & 980 & 528 & 46 & 113 \\
\hline 5142 & $\begin{array}{l}\text { Data processing, hosting, \& related } \\
\text { services }\end{array}$ & 5.01 & 3,832 & 288 & 342 & 350 & 75 & 388 \\
\hline 52413 & Reinsurance Carriers & 41.01 & 945 & 70 & 84 & 116 & 9 & 123 \\
\hline 5411 & Legal services & 2.22 & 6,616 & 638 & 594 & 600 & 169 & 684 \\
\hline 541330 & Engineering services & 0.80 & 5,700 & 488 & 539 & 575 & 189 & 656 \\
\hline 54151 & $\begin{array}{l}\text { Computer systems design \& related } \\
\text { services }\end{array}$ & 2.21 & 1,802 & 133 & 163 & 178 & 31 & 189 \\
\hline 54161 & Management consulting services & 3.17 & 2,356 & 211 & 205 & 196 & 41 & 251 \\
\hline 541710 & $\begin{array}{l}\text { Research \& development in the phys, } \\
\text { engineering \& life sciences }\end{array}$ & 4.82 & 4,668 & 480 & 450 & 524 & 96 & 593 \\
\hline 611 & Educational services & 49.61 & 668 & 59 & 55 & 53 & 9 & 89 \\
\hline 711 & $\begin{array}{l}\text { Performing arts, spectator sports, \& } \\
\text { related industries }\end{array}$ & 0.49 & 1,262 & 80 & 115 & 107 & 15 & 148 \\
\hline 8113 & $\begin{array}{l}\text { Com \& industrial mach \& equip (except } \\
\text { auto/elect) repair \& maintenance }\end{array}$ & 29.79 & 5,950 & 538 & 558 & 2,413 & 145 & 711 \\
\hline \multicolumn{9}{|c|}{ Correlation between services trade and pollution } \\
\hline \multicolumn{3}{|c|}{ - correlation with column (1) } & -0.42 & -0.26 & -0.41 & +0.13 & -0.32 & -0.25 \\
\hline \multicolumn{3}{|c|}{ - correlation without sector 8113} & -0.60 & -0.43 & -0.51 & -0.57 & -0.48 & -0.47 \\
\hline \multicolumn{3}{|c|}{ - correlation without sectors 52413 and 611} & -0.27 & -0.12 & -0.29 & +0.27 & -0.18 & -0.11 \\
\hline \multicolumn{3}{|c|}{ - correlation with trade intensity with Canada } & -0.59 & -0.39 & -0.53 & -0.58 & -0.49 & -0.44 \\
\hline \multicolumn{3}{|c|}{ - correlation with trade intensity with Mexico } & -0.41 & -0.38 & -0.27 & -0.41 & -0.37 & -0.41 \\
\hline
\end{tabular}

Notes: Trade data for 2002

Source: calculations from TEAM and BEA. 